\title{
CIRCULAR HOSPITAL WARDS: \\ PROFESSOR JOHN MARSHALL'S CONCEPT AND ITS EXPLORATION BY THE ARCHITECTURAL PROFESSION IN THE 1880s
}

\author{
by
}

\section{JEREMY TAYLOR*}

The readers of the Builder, the architectural profession's pre-eminent journal during the second half of the nineteenth century, would have been aware in the early 1880 s of a sudden flowering of interest in the idea of circular hospital wards. This represented a variant on the rectangular wards of the detached "Nightingale" pavilion form, which architects had by then become accustomed to as the perceived orthodoxy following the strong lead and continuing support given by the Builder's most famous editor, George Godwin FRS, during the late 1850s and the 1860s.

The trigger to this exploration by architects and their clients of a novel concept in ward design came directly from a paper given by John Marshall FRS, Professor of Surgery at University College and Hospital, and Professor of Anatomy at the Royal Academy, ${ }^{1}$ to the Cheltenham Congress of the Social Science Association in $1878 .{ }^{2}$ This was reported virtually complete by Godwin in the Builder under the heading 'On a circular system of hospital wards', ${ }^{3}$ and was published the same year as a pamphlet with comments and criticism added by P. Gordon Smith FRIBA, the Architect to the Local Government Board. ${ }^{4}$ The presentation was also covered fully in the British Medical Journal with the essence of it repeated, approvingly, for the same readership some four years later. ${ }^{5}$

In the paper Marshall presents the case for a circular ward plan (instead of a rectangle) with his strongest arguments addressed to improved opportunities for light, air, and ventilation. His headings include "freedom of frontage" for the ward to all

* J. R. B. Taylor, MA, PhD, RIBA, 140 The Mount, York YO2 2BW.

${ }^{1}$ John Marshall (1818-1891), anatomist and surgeon, born Ely. Professor of Surgery at University College 1866-84; Professor of Anatomy at the Royal Academy from 1873 until his death. The DNB notes that his "fame rests greatly upon the ability with which he taught anatomy in its relation to art", and also "his great facility in drawing" (cf. Anatomy for artists, 1878). As a surgeon Marshall's name was linked with galvano-cautery and the operation for the removal of varicose veins. FRS 1857. President Royal College of Surgeons 1883. Obituaries Lancet, 1891, i: 117; Br. med. J., 1891, i: 93; Proc. Royal Soc. An account of Marshall's family life is given in Z. Shonfield, The precariously privileged, Oxford University Press, 1987.

${ }^{2}$ Trans. natn. Ass. Promotion social Sci.: Cheltenham meeting 1878. London, 1879, pp. 520-26. The Transactions did not print the ensuing discussion, but a brief coverage can be found in Br. med.J., 1878, ii: 678.

${ }^{3}$ Builder, 2 Nov. 1878, 36: 1140-41.

$4 \mathrm{~J}$. Marshall, On a circular system of hospital wards, London, Smith Elder, 1878, 22pp, including remarks and illustrations by P. G. Smith. The frontispiece to the pamphlet shows block layouts for hospitals with circular wards arranged on different shaped sites, plus two notional ward plans.

${ }^{5}$ Br. med. J., 1878, ii: 678. In ibid., 1882, ii: 349,351 , Dr Dawson Williams of University College, in 'Remarks on the advantages of the Circular Ward system', appended to a note of Marshall's on the Antwerp Hospital, presented a restatement of the concept, and quoted widely from the pamphlet. 
quarters of the compass; and he noted that a circular ward, "having no blank ends like an oblong ward . . . would receive light, air, and wind from every direction", thus underscoring this aspect of air flow as a prime consideration. With the ward's openings and corridors disposed evenly around it, Marshall made an analogy with the circular tent, and the freedom of natural ventilation that implied. For artificial ventilation he suggested a centre (extract) shaft "equidistant from the circumferential inlets" and asserted that "sharp draughts across the ward, down draughts on the walls opposite and relatively near to open windows . . . would not exist" 6

To explain advantages in the use of the floor space and volume, Marshall postulated a ward with an internal diameter of $61 \mathrm{ft}$., accommodating 22 or 18 beds, each occupying $8 \mathrm{ft}$. or $9 \mathrm{ft}$. 6in. respectively of boundary wall space per bed; and then made beneficial comparisons against a rectangular format with the same number of beds and bed head spacing. He also noted the extra floor space and volume per bed achieved by the resultant geometry of the circular ward as a bonus; but omitted from his argument the implied extra costs, which were to become one of the major areas for later criticism.

He failed to emphasize one very obvious potential for the circular format-that of fitting a new ward onto an existing or constricted site. The omission is more surprising because Marshall, in claiming to have initiated the idea of the circular ward in England, said that his attention had been directed to it by considering the method of carrying out future extensions to University College Hospital. ${ }^{7}$

I may here add, that simultaneously with the writing of this paper ... I prepared a set of sketches to a scale, with a description showing how this system might be applied to the site of University College Hospital. These plans and elevations show four circular Ward Towers, each consisting of an arched basement, three storeys of wards, accommodating fifty-four beds, and an upper glazed exercise and day room. The circular blocks thus formed stand at the four corners of a quadrangular site, and are joined by corridors to square-shaped administrative blocks having the general form of a Maltese Cross, and occupying the interval between the Ward Towers. ${ }^{8}$

A block plan by Francis E. Jones, architect, for a hospital on the circular ward system "adapted to a confined site such as that of University College Hospital", evidently illustrated this concept when it appeared as exhibit no. 81 at the International Medical and Sanitary Exhibition of 1881 (fig. 1). ${ }^{9}$

\footnotetext{
${ }^{6}$ Builder, 2 Nov. 1878, 36: 1141. Marshall considered that the "difficulties attendant upon ventilating a long ward would disappear", and he saw the problems of deficiency of movement of air with certain winds, and the unequal or opposing extracting power of two or more fireplaces, as being overcome.

${ }^{7}$ Builder, 20 Dec. 1884, 47: 815.

8 Trans. natn. Ass. Promotion social Sci., op. cit., 526. Marshall noted in his pamphlet's Preface that his study for developing a "certain site" (University College Hospital) had led to the whole circular ward idea. Marshall, op. cit., note 4 above.

${ }^{9}$ London medical Record, 15 July 1881, 296-97. The description gives wards of $60 \mathrm{ft}$. internal diameter, with 21 beds each, together with figures for floor and wall space/bed and volume. It also notes the "external polygonal shape given to ward towers, is for appearance sake, as well as with a view to economy, owing to the extra cost of 'circular work'; internally the wards to be circular." Interestingly, exhibit 59 at the same Exhibition of 1881 was also a scheme for the reconstruction of University College Hospital on its present site, by Dr G. V. Poore and A. Waterhouse ARA. This proposed three separate rectangular pavilions, each five storeys high, forming a letter ' $E$ ' shape on the site. It was a scheme by Alfred Waterhouse that was finally built 1897-1905. See Trans. sanit. Inst. Gt Br., 1881-2, 3: 56ff. Comments by Dr F. J. Mouat on the Poore/Waterhouse plan are in Lancet, 1881, ii: 410 .
} 


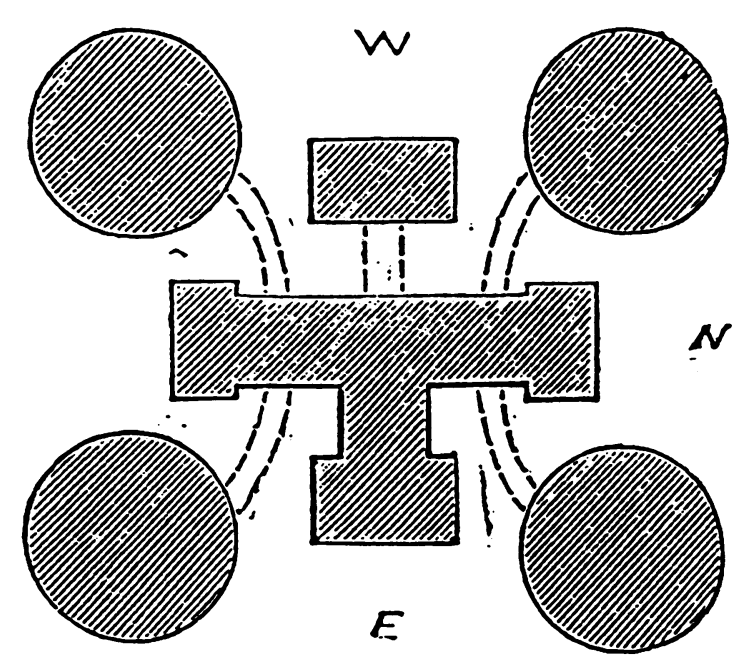

Figure 1: A hospital on the "circular ward system" of Professor John Marshall, FRS, adapted to a confined site such as that of University College Hospital. Drawings by Francis E. Jones, architect; exhibit no 81 at the 1881 International Medical \& Sanitary Exhibition, London. (The London Medical Record, 15 July 1881 , p. 296).

Marshall considered the internal supervision by nursing staff "easy", although at the same time made it quite clear that he would envisage the central core, with a source of radiating heat, as a "focus" to a circular ward. ${ }^{10}$ So any residual arguments on that best known aspect of "panopticism", central surveillance, were not seen to apply here in Marshall's proposal (and indeed in the whole of the published material in the architectural press on circular wards there is no direct reference to the panoptical format). What, however, may have been more persuasive were the practical and self-evident advantages of circular forms, for example related to the idea that air, like dirt, can get stuck in awkward corners. ${ }^{11}$ Marshall also pointed out to his Cheltenham audience that he had "considered the obvious alternatives of an elliptical or a polygonal shape" but while these might be easier for construction, there would be angles and corners where no beds could stand, and there "would be unoccupied and probably dirty and comparatively stagnant corners". ${ }^{12}$

\footnotetext{
${ }^{10}$ Marshall, op. cit., note 4 above, p. 20.

${ }^{11}$ Arguments on this theme had been around for some time, and might well have been familiar to Marshall. For instance, Jeremy Bentham, in Panopticon; or, the inspection house ... (3 vols., London, T. Payne, 1791, p. 115) referred to a paper by the Dijon physician, M. Maret: 'Mémoire sur la construction d'un hôpital . . .', Nouveaux mémoires de l'Académie de Dijon, prémier semestre, 1782, pp. 25-68. Maret believed that curved walls and ceilings facilitated ventilation. I am indebted to Dr Christine Stevenson for this reference.

${ }^{12}$ Trans. natn. Assoc. Promotion social Sci., op. cit., note 8 above, p. 525. Could Marshall have been aware of the final (1876) plan by John S. Billings for two octagonal ward blocks with 24 beds per ward, at the Johns Hopkins Hospital, Baltimore? One three-storey block was eventually built in 1885 . See J. D. Thompson and G. Goldin, The hospital: a social and architectural history, Yale University Press, 1975, 184, fig. 189 a-c.
} 


\section{Circular hospital wards}

In his 'Remarks' in the pamphlet presenting Marshall's proposals, the architect $\mathbf{P}$. Gordon Smith noted four features "deserving of special attention": adaptability to site; adaptability to special purposes; facilities in regard to construction; and appearance. Under "construction" he developed the role of a central ventilating shaft/chimney stack as an important structural element, with iron girders radiating from it to support an infill of concrete and provide fireproof floors. ${ }^{13}$ Marshall noted the opportunity for "Ward Towers"-at most three floors-with a basement for a heating and ventilation plant, and a roof (by implication flat) with a warmed central day room, glazed corridor/winter garden, and an outer walk for the use of convalescent patients. ${ }^{14}$

Smith did, however, sound a note of caution over the extra cost of the circular over the rectangular form, and equally that of a flat terraced roof for exercise over the traditional pitched and slated one. He then, in the published pamphlet, introduced the argument which, for many architects, may have been the most seductive of all:

\footnotetext{
It now only remains for me to say a few words regarding the appearance of a circular block of wards. Perhaps it will be enough for me here to refer to the favour which circular buildings seem to have found with artists from remote times down to the present day. Whether we look at the Castle of St. Angelo or the tomb of Cecilia Metella at Rome, the Baptistry, or even the Leaning Tower at Pisa, the curved apses of many churches, or the Albert Hall at South Kensington, I do not think we shall find much difference of opinion as to the satisfactory appearance of which the circular or elliptical form of building is capable. The building may be enriched by recesses, alcoves or balconies, or it may be quite plain, but the circular form of itself may be trusted always to produce charming effects of soft light and shade. In fact, the circular form of hospital ward, in skilful hands, would lend itself in the most happy manner to the production of buildings which would undoubtedly be the pride of the towns possessing them. ${ }^{15}$
}

This seemed to offer to an architect involved in the increasingly complex and client-driven problem of hospital design, where well-defined rules for the pavilion ward format already existed, the opportunity to secure some interesting visual effects, coupled with the attraction of emphasizing the formal and geometrical qualities of such buildings in the townscape. More importantly perhaps, it could also be argued that this new and distinctive ward form might also allow architects to regain some of the design initiative they were seen to be losing by the application of standardized plans. Marshall, in his paper, had also argued that within circular wards there could well be additional benefits of space, light and visual pleasure for all those using them. As the Builder was subsequently to remind the architectural profession, such considerations "can only be advanced after it has been satisfactorily shown that the practical advantages of the form are paramount; but, that granted, it counts to something additional in its favour". 16 The question of practical advantages were just those that were to come into question during the discussion following Marshall's paper to the Cheltenham Congress. In reporting the occasion, the British Medical Journal recorded: “Capt. Douglas Galton did not consider that any advantage would

\footnotetext{
${ }^{13}$ Marshall, op. cit., note 4 above, p. 20.

14 Ibid., p. 21.

15 Ibid., p. 22.

${ }^{16}$ Builder, 20 Dec. 1884, 47: 816. For the Builder's advocacy of the pavilion format, see Anthony King, 'Hospital planning: revised thoughts on the origin of the pavilion principle in England', Med. Hist., 1966, 10: $360-73$.
} 


\section{J. R. B. Taylor}

accrue by the adoption of the plan proposed, nor did he approve of the system of ventilation suggested. Oblong wards permitted of proper window lighting and natural ventilation, which circular wards did not .... The general opinion of the section appeared to be adverse to Mr Marshall's propositions". ${ }^{17}$

Despite a passing reference in the Builder to a proposal, in 1879, to put Marshall's ideas into practice at Spalding ("an untried experiment and a costly one"), ${ }^{18}$ the first real manifestation for architects was the publication in 1881 of Henry Saxon Snell's book Charitable and parochial establishments. ${ }^{19}$ As a leading exponent of the workhouse-infirmary building type, the architect Saxon Snell ${ }^{20}$ gathered together in this a selection of his major designs (many by then built, e.g. St George's Union Infirmary, now St Stephen's Hospital, Fulham; St Marylebone Infirmary, now St Charles Hospital, Kensington, and with them included a notional 'Design for an Infirmary with Circular Wards' (fig. 2). ${ }^{21}$ This shows a complete site layout incorporating seven circular ward towers, each of three storeys. Each ward, of approximately $70 \mathrm{ft}$. in diameter, would have 32 beds, and the infirmary a total of 700 inmates (or 476 if two storeys, or 980 if four storeys). The accommodation of the

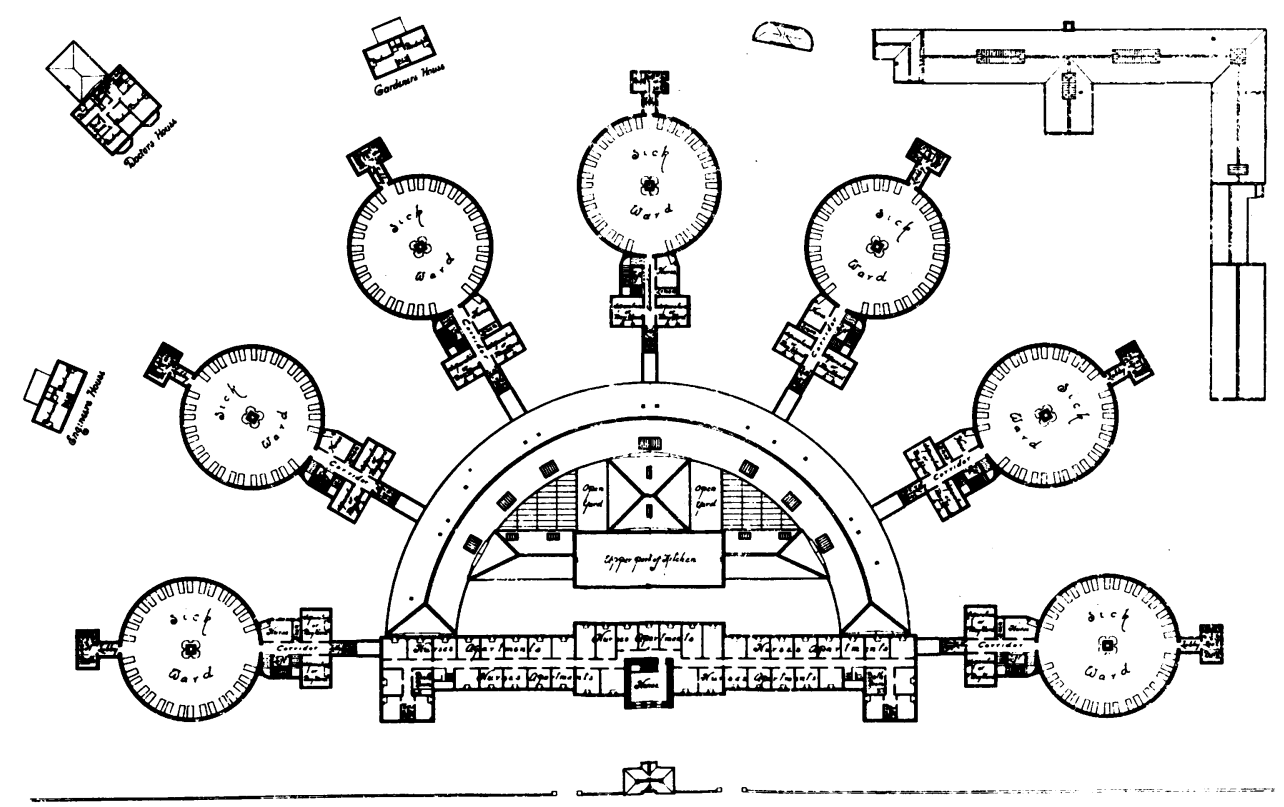

Figure 2: Design for a Workhouse Infirmary with Circular Wards, Upper floor plan (H. Saxon Snell, Charitable and parochial establishments, 1881).

17 Br. med. J., 1878, i: 678.

18 Builder, 20 Dec. 1884, 47: 815.

19 H. S. Snell, Charitable and parochial establishments, London, B.T. Batsford, 1881.

${ }^{20}$ Henry Saxon Snell FRIBA (1832-1904). For a list of his works see the obituary in the Builder, 16 Jan. 1904, 86: 64. His two sons, Harry and Alfred Saxon Snell, were in practice with him at different times.

${ }^{21}$ Snell, op. cit., note 19 above, pp. 13-15, plans. 

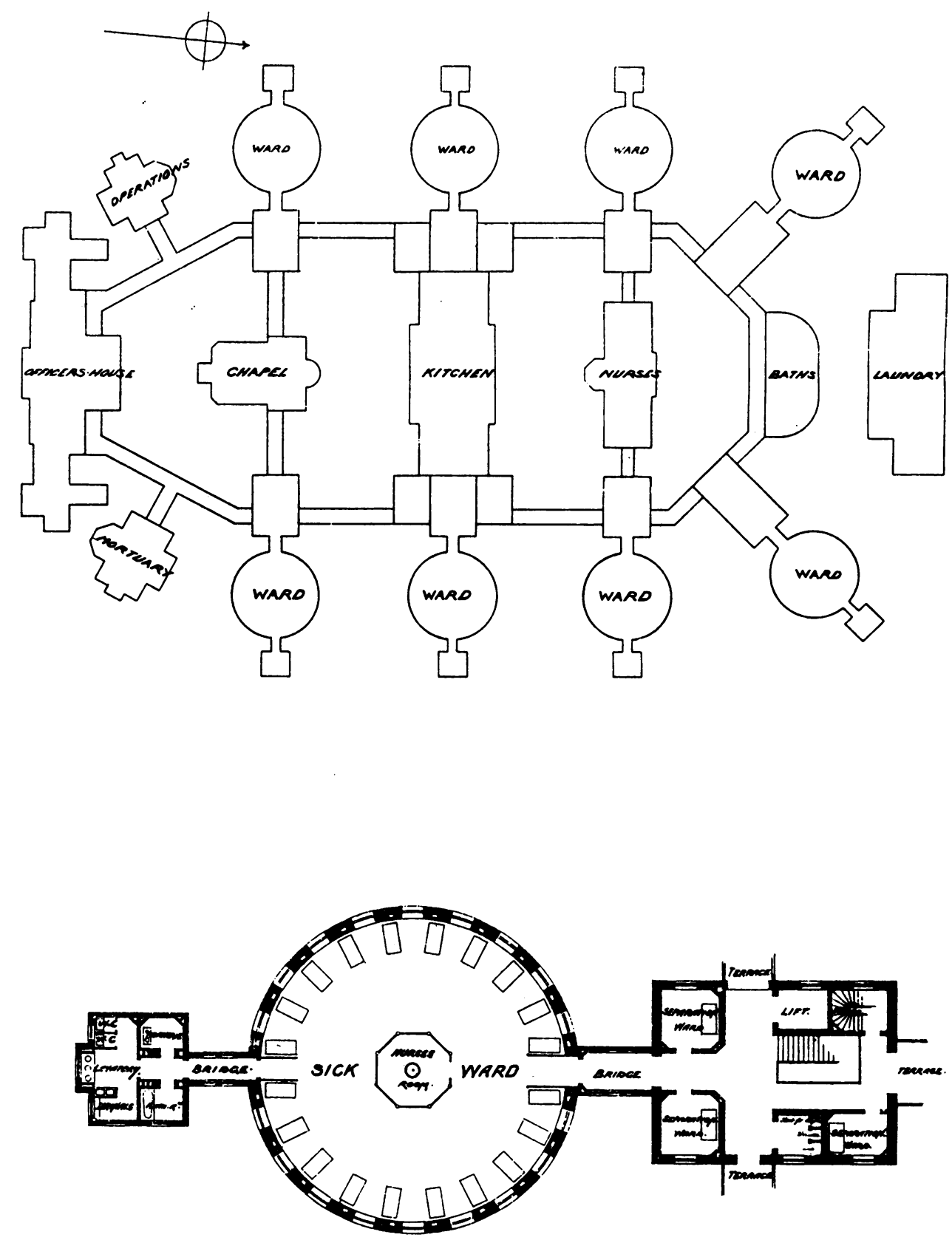

Figure 3: Civil Hospital, Antwerp 1878-1885. Architect Baeckelmans (Builder 7 July 1883). 
infirmary is drawn out in detail for each floor, and a full schedule of accommodation given. The design of the standard ward floors responded to Marshall's proposal (although somewhat, and perhaps uncomfortably, larger in diameter), and established the basic architectural elements that were later to be manipulated by other architects during the 1880s. These comprised the ward itself with the central ventilating shaft and fireplace; and two entrance points to the ward from first, a vertical access block with a nurses' office having a window onto the ward, stair, lift, small separation or day ward, store and access corridor; and second, a vertical bath and WC block with a ventilated lobby. This, therefore, represented a logical adaptation of the accepted "pavilion" format. Saxon Snell's overall infirmary layout is on the radiating principle, and he provided a block sketch showing how rectangular wards could have been used instead. The design is prefaced by a full extract from Professor Marshall's pamphlet, and Snell's own brief comments make clear his support: "There is no doubt that the plan, if carried out, would be found to afford many advantages not be to attained by rectangular-shaped Wards, and the only argument that could be urged against its adoption is that it is, as pointed out by $\mathrm{Mr}$ Smith, more expensive in first cost". As the first fully-drawn essay on the type, this provided a valuable exemplar for the architects and clients of the various schemes (mostly for workhouse infirmaries, albeit for single ward blocks) that began to be commissioned from 1882 on.

What also became clear to Marshall in March 1879 was that, unknown to him, the same year as his paper was delivered (1878) construction had begun on a new Civil Hospital in Antwerp with a complete system of eight circular ward pavilions (fig. 3). ${ }^{22}$ The latter were each of two floors, with the wards for twenty beds of $61 \mathrm{ft}$. 6in. internal diameter. ${ }^{23} \mathrm{~A}$ later discussion of the origins of the circular wards idea, which was held in 1884 at a Hospitals Association meeting, indicated that the first design for Antwerp may have dated from 1872, and that prior to that, Gen. Sir Andrew Clarke RE had put forward proposals (none carried out) for circular ward hospitals at Madras (1852), Yokohama, and Lucknow. ${ }^{24}$ Clarke, who was present at the 1884 meeting, disclaimed originality and said that the idea "had been first suggested to him in 1854 by $\mathrm{Dr}$ M'Kenna, of Melbourne, a military doctor, who had found in the course of active service elsewhere that when the wounded were placed in convent rooms, hospital gangrene usually set in; when they were placed in a circular church, hospital gangrene seldom set in, and a in a much milder form when it did". Clarke had also been "reminded of this by the experience with the wounded at Rome in Garibaldi's campaign, when the Pantheon was made use of as a military hospital with the most favourable results". This line of argument, which wandered off to the possible

\footnotetext{
${ }^{22}$ See John Marshall, 'A note on the new hospital at Antwerp' in Br. med. J., 1885, ii: 349, 350 (plan); also F. J. Mouat and H. S. Snell, Hospital construction and management, London, J. \& A. Churchill, 1883, ii: 79; Builder, 30 June 1883, 44: 878. Marshall's daughter Jeanette records " $P[a p a]$ hears that some foreigner has had the idea of Circular Hospitals too, $\&$ and that one is actually being constructed at Antwerp. Rather tiresome". Shonfield, op. cit., note 1 above, pp. 139-40.

${ }^{23}$ Hospital block plan and ward plan in Builder, 7 July 1883, 45.

24 Builder, 20 Dec. 1884, 47:815, and Br. med. J., 1884, ii: 1258. The latter remarked that the fact "that this special system of construction should have suggested itself, quite independently, to no fewer than three persons, is in itself strong evidence that the plan possesses certain conspicuous advantages".
} 


\section{Circular hospital wards}

benefits of a circular form per se, was firmly and quickly quashed in the editorial reporting the occasion, and suitable reminders were added for the architectural profession that cleanliness, impervious materials, and the larger cubical content in the churches mentioned was what really lay behind any improvements noted. ${ }^{25}$ And it is clear that it was just such functional arguments which provided the mainspring for Marshall's detailed proposals.

Antwerp was fully commented on during 1882 and 1883 in the British Medical Journal (by Marshall), the Builder, and in Saxon Snell's next book (as joint author with Dr Frederic J. Mouat) Hospital construction and management. ${ }^{26}$ Considerable interest was shown in this as "the only practical experience on a large scale which has yet been made with circular wards" 27 -although the building was not noted as being completed until 1885. From the start, Antwerp was criticized in Belgium, and, as soon as the design was published, in England. (And the criticisms, although related to differences in design approach from Marshall's, may well have fuelled the reaction to the circular ward form which began to set in amongst architects by the mid-1880s). The original design for Antwerp, by the architect Baeckelmans, received approval by the town administration but was initially, in 1875 , condemned by the Council of Public Hygiene at Brussels. ${ }^{28}$ The Council noted that superintendence from a glass cabin in the centre of the room was not easier; that nurses would be located in the middle of any epidemic throughout the working day; and that while the volume of air might be larger per patient, the problems of changing the air were correspondingly greater. It was these points that attracted the most critical comment from Godwin (and later Saxon Snell, Captain Douglas Galton, and Professor de Chaumont). ${ }^{29}$ The central cabin idea did not feature in Marshall's proposals, or in any of the English designs, in which flues, shafts, fireplaces or stairs always occupied that location at the focus. Godwin reinforced an obvious fear that "After the building [i.e. Antwerp] had been in use for some years there would be a melancholy interest in obtaining statistics of the rate of disease and mortality of the nurses thus spending the best part of their time in the centre of a ward surrounded by patients". ${ }^{30}$

This fear was lent greater credence by the realization that the Antwerp ventilation system was the complete opposite of Marshall's scheme. ${ }^{31}$ Instead of warmed fresh air coming in through grilles near each patient's bed head, and stale air being withdrawn at high level from the central core, exactly the inverse was proposed for Antwerp and it would, therefore, require a more powerful (and machine-dependent) system of forced ventilation, including fans, to make it consistently effective. At Antwerp, Baeckelmans refused to carry out any modification to his design, and the building was finally completed by his pupils Belmeyer and Van Kiel. ${ }^{32}$ In approving the

25 Builder, 20 Dec. 1884, 47: 815.

26 Br. med. J., 1882, ii: 349; Builder, 30 June 1883, 44: 877-8; Mouat and Snell, op. cit., note 22 above.

27 Builder, 7 July 1883, 45: 4.

28 Mouat and Snell, op. cit., note 22 above.

29 Builder, 7 July 1883, 45: 4. Snell stated in the Builder (26 Sept. 1885, p. 443) that "No other Continental nation has, to my knowledge, considered this new system worthy of imitation . . .".

${ }^{30}$ Builder, 7 July 1883, 45: 4.

31 Ibid.

32 Mouat and Snell, op. cit., note 22 above. 
modifications in 1876, the Council of Public Hygiene declared that they did "not make the admission or rejection of the circular system a vital point; the recognise it is an innovation and an experiment, and they wait the result with all possible reserve". ${ }^{33}$ Whatever alterations were made failed to impress Captain Douglas Galton when he visited the first four occupied pavilions in mid-1885: he complained of too many beds, set too close and not arranged in relation to the windows; unfit conditions for the nurses; and the largely artificial ventilation of the wards (but the machinery "out of repair" and not working). ${ }^{34} \mathrm{~A}$ rather different point of view had been expressed by Marshall when he and his family inspected the partially-complete Antwerp project on their return from an autumn holiday in Germany in $1884,{ }^{35}$ he referred to the "surprise and delight" they all felt at "the singularly light and cheerful aspect of the interior of one of the circular wards".36

The year following the first discussions and criticism of Antwerp saw the opening (on 17 December 1884) of the first English circular wards, at the 'Miller' Memorial Hospital, Greenwich ${ }^{37}$ The British Medical Journal drew attention to this as "of very special interest to hospital committees" and noted "to Professor John Marshall belongs the credit of having independently thought out the scheme, and of having brought it prominently before architects in this country; . . anybody who will pay a visit to the hospital at Greenwich will be convinced that many of the objections urged against the system are not borne out by experience." 38 Construction of circular wards was also well advanced at Hampstead Infirmary (New End), and in progress at the Victoria Hospital, Burnley, and the Seaforth Cavalry Barracks, Liverpool. ${ }^{39}$ In America, the ideas of Marshall and the example of Antwerp appear to have been taken up at the Cancer Hospital, New York. Erected in 1884 "at the sole cost of Mr J. J. Astor", the design, by the architect Charles C. Haight, consisted of a rectangular block with four-storey circular towers at three of the corners. In two of these, the whole floor on two levels was given over to circular wards for eleven beds each. Burdett, reporting on this, noted that the site, at the corner of two wide streets, was limited in area. ${ }^{40}$

At Hampstead, the guardians of the Parish of St John had decided on a circular ward pavilion block as an extension of the workhouse Infirmary. ${ }^{41}$ Completed in 1885 , to the

\footnotetext{
${ }^{33}$ See Henry C. Burdett 'Circular hospital wards' in Lancet, 1885, ii: 684.

34 Builder, 17 Oct. 1885, 49: 549, 550.

35 Shonfield, op. cit., note 1 above, 140.

${ }^{36}$ Builder, 3 Jan. 1885, 48: 10; but this was not the view of de Chaumont, for whom they were "by no means attractive" (Builder, 17 Oct. 1885, 49: 550).

${ }^{37}$ Builder, 20 Dec. 1884, 47: 815: "the first ... to be put into actual working". The opening was followed by a meeting at the rooms of the Social Science Association to consider the subject of circular wards generally. This was addressed by Prof. Marshall and the buildings's architect Keith D. Young. Plan and elevation in the Builder, 23 Aug. 1884.

${ }^{38} \mathrm{Br}$. med. J., 1884, ii: 1258 . The foundation stone had been laid in early August 1883: see ibid., 1883, ii: 289. The journal also stated "This is to be in the circular form adopted in Belgium and America". The latter appears to be referring to the Cancer Hospital, New York (see note 40 below).

39 Builder, 20 Dec. 1884, 47: 815; Br. med. J., 1884, ii: 1258 also credits Gen. Clarke with another small military hospital having a circular ward, "at Milton, near Southend, for the School of Musketry".

${ }^{40}$ H. C. Burdett, Hospitals and asylums of the world, 4 vols., London, J. \& A. Churchill, 1891-3, vol. 4, p. 290 . The portfolio of plans (1893), sheet 89 . The wards were $37 \mathrm{ft}$. diameter on the first and second floors; the third tower was subdivided into private rooms.

${ }^{41} \mathrm{Br}$. med. J., 1884, i: 876; Lancet, 1884, i: 625.
} 
Circular hospital wards


Figure 4: Hampstead Workhouse Infirmary extension (1882-84). Architect Charles Bell (Builder 2 Feb. 1884). 
design of the architect Charles Bell, it represented the first example of the free-standing circular "ward tower" suggested by Marshall and given form in Saxon Snell's 1881 proposal (fig. 4) ${ }^{42}$ There are three floors of wards (50ft. in internal diameter, with 24 beds each) with cantilevered "airing galleries" facing the south-east, a basement services floor, and a top floor of nurses' rooms within the pitched roof space. ${ }^{43}$ Attached to the main brick drum is a stair tower, and a separate bathroom/wC and tank tower. The centre core contains downward extracting exhaust flues from the wards, and the main upcast flue to draw out and discharge the used air driven by the heat of the basement boiler system. A very similar design, but with four instead of three ward floors, was later completed in $\mathbf{1 8 8 8}$ as an addition to the St Giles Infirmary, Camberwell; the architect was R. P. Whellock, and in this case an initial polygonal scheme was apparently altered to a circular one. ${ }^{44}$

By contrast, the 'Miller' Memorial Hospital, Greenwich (wards 35ft. in diameter with ten beds each) of two floors, ${ }^{45}$ and the Cavalry Barracks Hospital at Seaforth, Liverpool (nine-bed ward) on one floor, ${ }^{46}$ represents a much smaller-scale approach, one considerably reduced from Marshall's envisaged optimum (figs. 5, 6). Both published in 1884, they can be seen to represent variants suitable for a small specialized ward, or as an addition to a local hospital of limited size. What, however, links the Hampstead and the Greenwich solutions firmly together is that in both cases very constricted sites, surrounded by other properties, forced the architects concerned to use the circular ward as the only way of achieving the required accommodation. ${ }^{47}$ As the British Medical Journal emphasized, in reporting the works in progress at Hampstead,

\begin{abstract}
This particular building ... brings out very well one of the chief advantages of the circular system of wards; that is to say, its peculiar suitability when the area available is limited. It is the most compact system upon which a hospital can advantageously be built. In this instance the area was limited, of an awkward shape, and still more awkward levels. If any one will take the plan ... and plot out an oblong ward having the same area as the circular one there drawn, he will be able to see how far more clumsy the oblong ward is, how much more it interferes with the passage of air and light to other parts of the buildings, and how very much less space is practically left to be utilised as a garden, or for other spaces. ${ }^{48}$
\end{abstract}

The design of Liverpool's Seaforth hospital, required for a new cavalry barracks, adopted the circular ward as an experiment to test "this newest principle of construction". ${ }^{49}$ The instigator was Maj.-Gen. Sir Andrew Clarke RE, Director General of Works at the War Office, whose project for a circular ward system at Madras, earlier than Marshall's paper, has already been noted. And it was Clarke who

\footnotetext{
${ }^{42}$ Snell, op. cit., note 19 above, pp. 14 ff.

43 Described and illustrated in the Builder, 2 Feb. 1884, 46: 162.

44 Information on this redesign from Dr Frank Kelsall. Compare the octagonal ward blocks at Johns Hopkins Hospital, note 12 above.

${ }_{43}$ Builder, 23 Aug. 1884, 47: 256.

46 Described, together with specification for sanitary and ventilation arrangements sent by the War Office to the Cummanding Officer Royal Engineers for guidance, in the Builder, 15 Nov. 1884, 47: 673, 674, with plate showing plan, elevation and section.

47 See the Builder, 2 Feb. 1884, 46: 162 and 20 Dec. 1884, 47: 816.

${ }^{48} \mathrm{Br}$. med. J., 1884, i: 876.

49 Builder, 15 Nov. 1884, 47: 673.
} 
Circular hospital wards
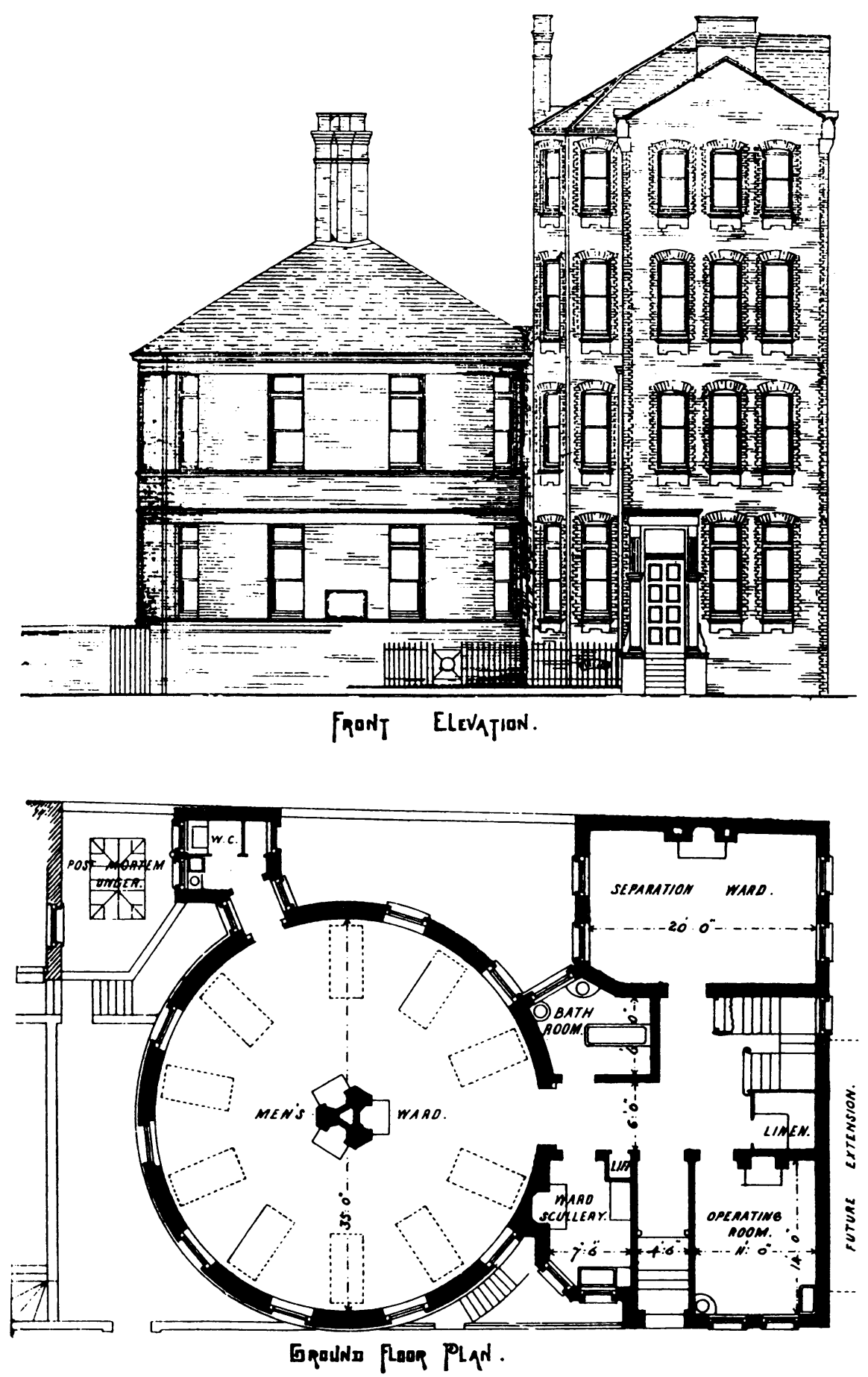

Figure 5: Miller Memorial Hospital, Greenwich. Architects Young and Hall (Builder 23 Aug 1884). 


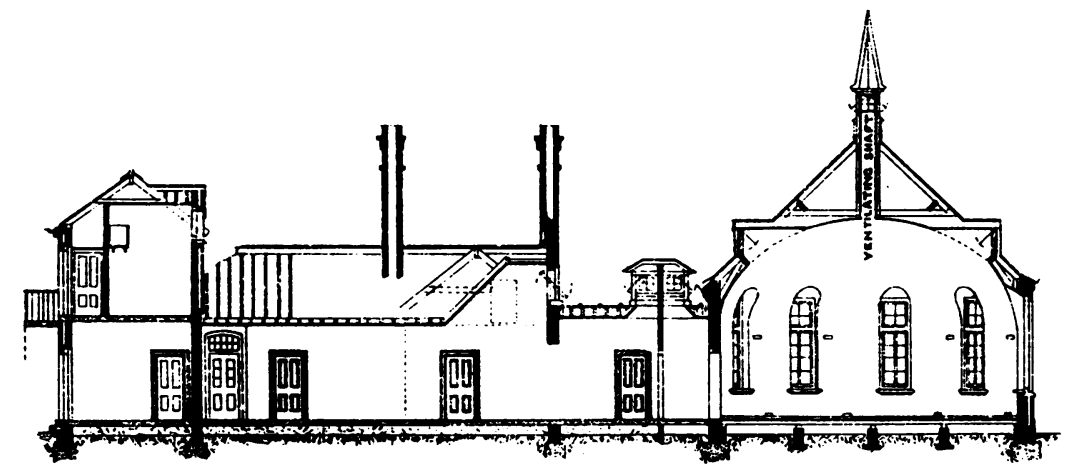

LONGTTUDINAL SECTION.

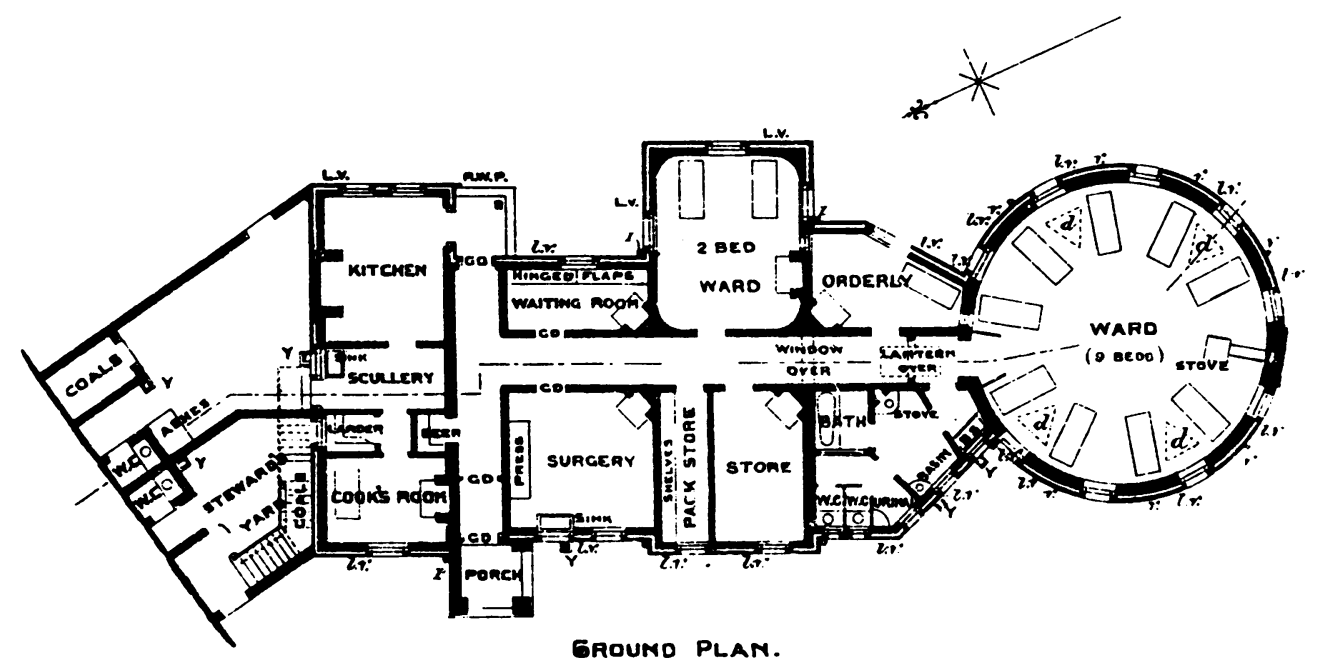

Figure 6: Seaforth Cavalry Barracks, Liverpool. Designed by Sir A. Clarke RE (Builder 15 Nov 1884).

was both part-designer and evidently client for what is the most astonishing, and certainly the most architecturally grandiloquent, of all the circular-ward hospital proposals. Published both in the British Medical Journal (April 1885) and in the Builder (May 1885), it is entitled in the latter 'Design for a Military Hospital for a Hot Climate' and the text notes that "the site . . consists of a rock promontory, jutting into the Mediterranean". 50 Sounding at first like the conditions for an ideal Beaux Arts student project, it was in fact for a site in Malta and the plan notes a location on the public road from Sliema to Valetta. ${ }^{51}$ The proposed hospital had nine one-storey

${ }^{50} \mathrm{Br}$. med. J., 1885, i: 710, 711 including a plan of a typical ward block; Builder, 9 May 1885, 48: 669, 670 and 3 plates.

51 Ibid. The plan also notes the location in Marsamuscetto Harbour at the Misida Creek. 


\section{Circular hospital wards}

circular wards (each of $66 \mathrm{ft}$. internal diameter for twenty-six beds) formally, and separately, disposed about a central street running along the ridge of the promontory on a great bastioned terrace (fig. 7). Around each ward ran an open arcade to provide shade, and on the flat roof above, a further open arcaded storey-known locally as a "Baracca"- to provide both an airing ground for convalescent patients, and as an overflow to double the capacity of the hospital in an emergency. In the centre of each ward (22ft. high with a shallow semi-elliptical ceiling) there was to be a cylindrical ventilating chamber running through the "Baracca" storey above. Beneath this, a central ring of columns and three majolica stoves would surround a majolica fountain playing in the centre of the ward space. The whole design was to be of the local stone in a classical idiom, with the central ventilating chambers suitably embellished as stone cupolas for each ward block. As the Builder calmly reported, it had a "more than usually marked architectural character". ${ }^{2}$ This character, and the eloquent overall
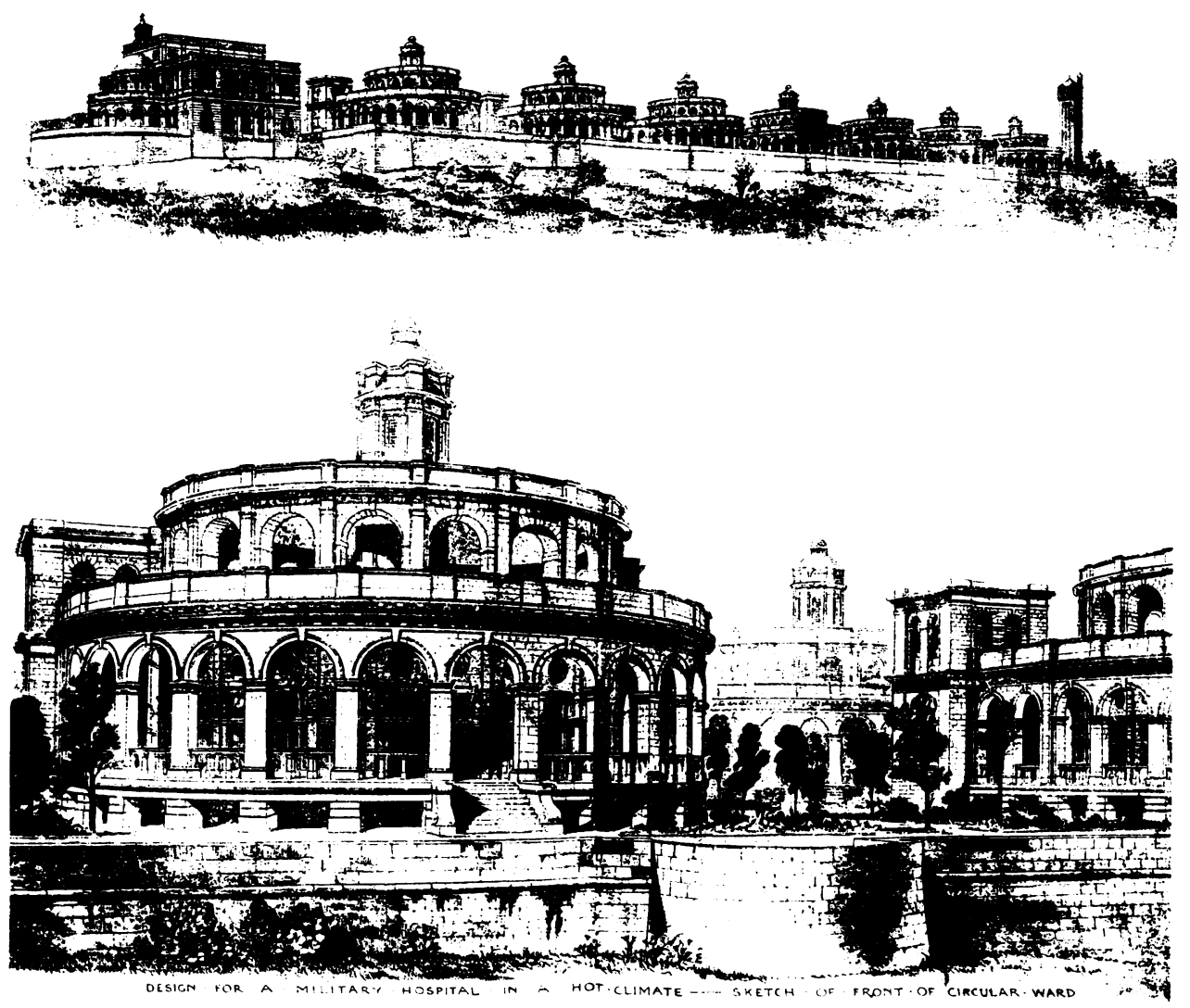

Figure 7: Design for a military hospital in a hot climate, by Sir A. Clarke RE and E. Ingress Bell FRIBA (Builder 9 May 1885).

52 Ibid., 670. But H. S. Snell, in the Builder (26 Sept. 1885), looked only at the planning, and was severely critical of the close spacing between beds in the wards. 


\section{J. R. B. Taylor}

plan for the hospital, was evidently the product of Sir Andrew Clarke's collaborator, the architect Edward Ingress Bell (1837-1914). Bell was by this time the partner of Sir Aston Webb, and the scale, and the quality of the perspective drawings (which were exhibited at the Royal Academy through the summer of 1885), ${ }^{53}$ befits the firm that was designing the Victoria Law Courts at Birmingham, was to win the competition for the new Victoria and Albert Museum 1891, and complete such major schemes as the Royal Naval College Dartmouth and Birmingham University.

The problems of the Mediterranean sun and heat served also to produce another unusual circular ward essay at this time. In the Builder of 3 January 1885 there is a letter signed by Professor John Marshall in which he forwards details of a proposed 'Hospital of one storey, with circular wards, for Egypt' designed by Viscountess Strangford in $1884 .{ }^{54}$ Essentially a single compact block of rooms surrounded by verandahs on all four sides, it had embedded in it four circular, domed windowless wards, two with twelve, and the other two with nine beds. Each ward was to have a roof lantern for lighting and ventilation, together with three entrance ways allowing for cross-circulation of air. In its concluding paragraphs, the communication reveals Professor Marshall's continued inventiveness, even at the expense of more practical matters:

Lady Strangford tells me that she proposes once a year to strip the circular wards of their destructible contents, to burn these latter outside the building, and to renew them. I suggested that the cremation should take place in the middle of the wards, and by the addition of sulphur or other fumigants, the fire itself would act as a purifier.

I have, indeed, often suggested that circular wards might be built, in sections, of iron, just as large caissons are; and then that they could be lined with wood or other material, which might periodically be burned and renewed. ${ }^{55}$

Perhaps after such proposals for Malta and Egypt, and the earlier dissatisfaction with Antwerp, it was inevitable that some more prosaic and critical reaction would occur. The occasion was the Congress of the Sanitary Institute of Great Britain, held at Leicester in September 1885, and the reaction an extremely critical paper on 'Circular hospital wards' from the architect H. Saxon Snell, ${ }^{56}$ who seems to have undergone a radical change of view from the unalloyed support he offered by his 'Design for a Workhouse Infirmary on Professor Marshall's system' of 1881. Snell's paper was followed by an equally hostile discussion. ${ }^{57}$ The only defender of the

53 Builder, 17 Oct. 1885, 49: 550.

54 Builder, 3 Jan. 1885, 48: 9, 10. This was proposed to be built at Port Said as a hospital for sailors and marines. The form was consciously modelled on the tradition of toplit, domed rooms in Egyptian houses. Lady Strangford had guided the work of the St John's Ambulance Association when it first arrived to set up a hospital in Cairo in September 1882, soon after the battle of Tel-el-Kebir. Br. med. J., 1882, ii: 1017.

55 Builder, 3 Jan. 1885, 48: 10.

56 Builder, 26 Sept. 1885, 49: 443-45. Snell's reappraisal appears to have followed his preparation of "a report to a public body prepared to erect this class of wards upon my recommendation". The paper is also given in Trans. sanit. Inst. Gt Br., 1885-86, 7: 205 ff.; Lancet, 1885, ii: 590-93.

${ }^{57}$ Builder, 17 Oct. 1885, 49: 549-50. 


\section{Circular hospital wards}

circular ward was the chairman, and President of the Section, P. Gordon Smith, whose drawings and comments had been adjoined to Marshall's original paper, and whose role as architect to the Poor Law Board had evidently been crucial in getting the Hampstead (New End) block approved. ${ }^{58}$

In introducing his paper, Saxon Snell acknowledged that "There is something very fascinating about the conception of a circular ward ... indeed, I was myself disposed, before critically examining the matter, to allow that this adoption might possibly be productive of some, if not all, the benefits promised by its advocates". But he concluded "I am convinced that the circular system as now advocated is wrong in any kind of hospital building, whatever be its special use or locality". 59

He then proceeded to work through the basic criteria, as they were then understood, for the planning and construction of general wards. Taking the acceptable number of patients per ward as 20 to 32, he showed how a notional hospital for 576 , with 540 patients in 18 rectangular wards of 30 beds, would require six three-storey pavilions. If, however, circular wards of the same floor space were used, 24 wards in eight pavilions would be required. The staff (twelve nurses, one scrubber, one porter), fuel, and support costs required for these extra two pavilions would be $£ 1000$ per year, or $£ 33,000$ capitalized at three per cent-and this represented the additional cost of maintaining 576 patients in wards on the circular system. He then tackled the question of the cost of building circular wards in relation to the necessary bed space, floor space, and volume standards, related to acceptable criteria; and demonstrated that for a circular ward of $65 \mathrm{ft}$. 6in. diameter (for 22 beds of the same bed-space standards as a rectangular ward) there must inevitably be a wasted central space of 896 square feet, or 12,553 cubic feet. "What then is to be done with this superfluous space? It has to be built, to be kept clean, to be ventilated, to be heated; but worst of all it has to be paid for ...". He then proceeded to detail the costs, including the two extra pavilions, furniture, heating, lighting, lifts, etc., to conclude that "... if the circular system is to come into vogue, we must be prepared for indulgence in the luxury (if it is one) at the rate of $£ 105,135$ for every 1000 patients".

In passing, he demolished the idea of a circular ward for thirty beds (to compare with a rectangular equivalent) noting it would have to be $87 \mathrm{ft}$. 9in. in diameter with the "waste of 2,705 sq. $\mathrm{ft}$. at its centre plus an extra $3 \mathrm{ft}$. of headroom". He then considered air circulation across a 60 -foot diameter, and noted that this could not be any more free than that across a rectangular ward 24 to 30 feet wide, and additionally challenged the notion of greater sunlight or improved "cheerfulness" in the circular ward. In conclusion he asked "even if the circular is as good as the parallelogram system what is left to compensate for the $£ 105,000$ outlay already referred to?"; and finished a painstakingly detailed and sustained attack by concluding that he could imagine no advantage. He studiously avoided any comment on difficult sites, architectural character, or the use of the central area for structure, heating and ventilating. ${ }^{60}$

\footnotetext{
${ }^{58}$ Builder, 2 Feb. 1884, 46: 162 notes "a long and exhaustive series of arbitrations and conferences with the officials of the Poor Law Board, in which the hearty sympathy and valuable suggestions of their architect, Mr Percival Gordon Smith . . were enlisted ...."

${ }_{59}$ Builder, 26 Sept. 1885, 49: 443.

${ }^{60}$ Ibid., 445.
} 


\section{J. R. B. Taylor}

Many of Saxon Snell's criticisms were logical and sustainable, and the record of the following discussion makes it clear that he had not only won over his Congress audience, but had the influential support of Captain Douglas Galton and F. de Chaumont, Professor of Military Hygiene at the Army Medical School, Netley. ${ }^{61}$ In his contribution, de Chaumont particularly noted Snell's adverse criticism of the wards in the Malta proposal, and saw the matter "as of very great importance, seeing that it [the circular ward system] is now strongly advocated by the Director of Works at the War Office ...". Foreseeing that a "very large expense will have to be incurred which will not be in any way commensurate to the advantages of the patient" 62 he concluded that he "would take care that Mr Snell's paper was brought before the notice of the War Office". 63

Snell drew the attention of Henry C. Burdett to his paper, printed complete in the Lancet. ${ }^{64}$ Burdett's resulting counter-article and the rather bad-tempered correspondence between the two (stopped by the Lancet's editor within a month) was to prove the only active dialogue on circular wards in the pages of the medical journals (and at that it was one between an architect and a medical administratorpolitician, rather than between doctors or medical reformers). Apart from disagreeing with Snell's figures and his correlation of hospital statistics, Burdett rejected Snell's construction of an edifice of detailed theories in order to denounce (as Burdett saw it, unfairly) one experimental form of hospital construction, without a sufficient practical examination. ${ }^{65}$ And he saw this compounded by the artificial scale at which Snell had presented his argument, for example, his use of costing comparisons for hospitals of 500 and 1000 beds as a basis for calculation. Whatever the reader's final impression of this welter of facts and figures, from both sides, it was clear that Henry Burdett was providing a tenable counter-attack, and that the circular ward could still forcefully be defended on the grounds of space use, function, and ventilation.

After this key meeting, and the ensuing correspondence in the Lancet, nearly all that was to be published against the principle of circular wards had been offered to counterbalance the advantages set out in Marshall's pamphlet. As seen by clients and architects reading the pages of the Builder, the professionals had looked at the theory of the circular ward and, after an exploration of the plan type and its functioning, had registered a note of considerable caution. The clients, reading the pages of the Lancet, would also have received some conflicting signals, albeit primarily from an architect rather than from leaders of medical opinion.

In October 1886 the new Victoria Hospital, Burnley was opened with due ceremony by Prince Albert Victor, and was seen to be of special interest as the two main wards

${ }^{61}$ Builder, 17 Oct. 1885, 49: 549-50; Trans. sanit. Inst. Gt Br., 1885, 7: 214 (Burdett and de Chaumont were joint editors).

62 Builder, 17 Oct. 1885, 49: 550.

63 Trans. sanit. Inst. Gt Br., op. cit., note 61 above, p. 214.

64 Lancet, 1885, ii: 590-3, 643. [Sir] Henry Burdett (1847-1920) formerly Secretary of Queens Hospital, Birmingham, and then of the Dreadnought Seamens Hospital, Greenwich, was much involved with hospital politics and health journal publishing. Architects were later to become familiar with his Hospitals and asylums of the world, cf. note $\mathbf{4 0}$ above.

${ }^{65}$ Lancet, 1885, ii: $684-86,691,738$. 


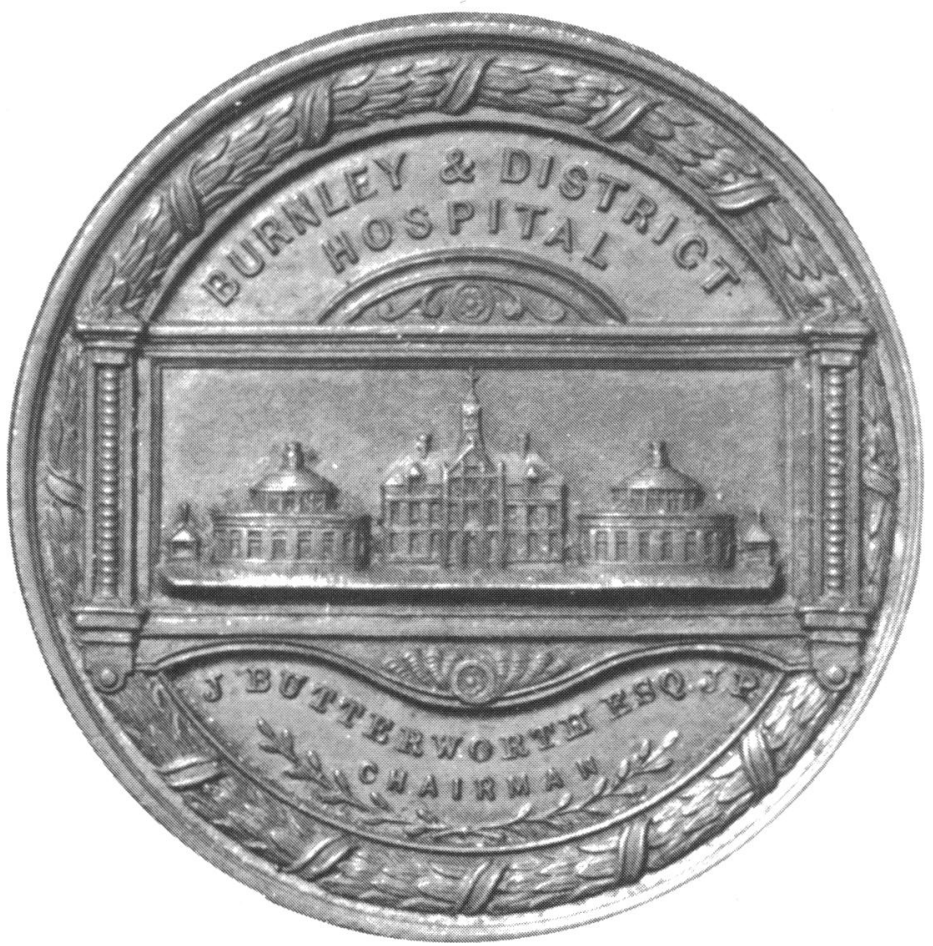

Figure 8: The Victoria Hospital, Burnley. Architects Waddington \& Sons. Foundation Medal 1884. (J. Taylor, The Architectural Medal 1978, 210a.) 
were circular, $60 \mathrm{ft}$. in diameter, single-storey, and for twenty patients each (fig. 8). Both the British Medical Journal and the Lancet had already run detailed news items when the design was approved in 1884, emphasizing the circular ward format "as suggested by Prof. Marshall, President of the Royal College of Surgeons". ${ }^{66}$ The Lancet had also noted that "Provision is made on the site for the addition of four other wards, similar in size to those described and also for a children's ward of fourteen beds". ${ }^{67}$ At the opening the Burnley Express enthused "It is confidently expected that many of the difficulties and danger arising from the known defects in even the later types of hospital construction will be avoided . . .", perhaps paraphrasing Marshall who in his address, on the advantages of circular wards, said "it was one of the proudest moments of his life to see in bricks and mortar, wood and machinery, an idea which had been floating in his mind for many years". A notable innovation was seen to be the sunrooms designed on the roof of each ward which were approached by "a spiral staircase of easy gradient in the centre of each block". These sunrooms were glazed all round and surrounded by a promenade twelve feet wide. ${ }^{68}$

The architectural attractions of using the roof of a circular ward as a parapetted terrace were similarly exploited in the design published the following year, for the Hastings, St Leonard's and East Sussex Hospital ${ }^{69}$ (by Young and Hall, architects of the 'Miller' Hospital, Greenwich, which was visited by the Sussex clients before they gave their approval for a circular system $)^{70}$ (fig. 9); and also in a competition scheme for the proposed West Ham Hospital in $1890 .^{71}$ In both cases, the overall planning of Burnley was adopted with a central rectangular administrative block and circular wards closely linked to it to left and right. This perhaps evoked, for smaller hospitals, a comfortable architectural image of the grand residence with its flanking pavilions.

Young and Hall were also the architects of the new Great Northern Hospital, Holloway Road, London. They were appointed following a limited competition in 1884 between five architectural firms, and their winning scheme included three circular pavilions, two of three storeys, and another of two storeys intended for future extension only. ${ }^{72}$ "After much consultation" between the Committee and its architects, it was decided to provide accommodation for all 150 patients at once, and to effect this by building one circular ward pavilion ( $56 \mathrm{ft}$. 6in. int. diameter for twenty beds on each of three ward floors) and one rectangular block, which was to be built as

${ }^{66} \mathrm{Br}$. med. J., 1884, i: 335-36; Lancet, 1884, i: 320. The foundation-stone laying on 24 May 1884 was commemorated by a medal showing the two circular wards. J. R. B. Taylor, The architectural medal: England in the nineteenth century, London, British Museum Publications, 1978, 171, illus. 210a.

67 Lancet, 1884, i: 320; the children's ward was to be 40ft. in diameter with a dome-shaped ceiling, but no central staircase or sunroom.

${ }^{68}$ Builder, 30 Oct. 1886, 51: 644. The promenade's floor, i.e. the roof of the ward below, was of concrete with an asphalt surface, on W.I. bearers. Burdett, op. cit., note 40 above, vol. 4, p. 41 , also noted an innovation for the bedsteads. These were made narrower at the foot to "lessen the effect of the diminuation of the floor space between the feet of the beds". This is a perennial problem with a radiating plan.

69 Builder, 29 Jan. 1887, 52: 180, 186, 187.

70 Ibid., p. 180.

${ }^{71}$ Builder, 18 Jan. 1890, 58: 44, 45 and plate. By A. Crow and P. H. Tree. They acknowledged adopting "the system advocated by Professor Marshall", and use the roof for an "airing-flat", as the very restricted nature of the site did not permit any garden for convalescents.

${ }^{72}$ Builder, 25 Dec. 1886, 51: 907. 


\section{J. R. B. Taylor}

the first phase. ${ }^{73}$ Lack of funds meant that the contractors could proceed only with the rectangular block for sixty patients, ${ }^{74}$ and this was open for view in 1888 . For the second phase, the constraints of the tight site meant that the only practicable solution to achieve the accommodation was to use the more innovative circular ward pavilion. Looking forward to this circular block with its virtually identical floor space and numbers of beds, the British Medical Journal realized "It will thus be seen that when finally completed an interesting experiment will be carried on within the walls of this institution, which should go far to settle claims made as to the rival merits of the oblong and circular ward systems." 75 So here, as at Hastings (where two schemes had been submitted for the wards, one "of the usual form", the other using the circular
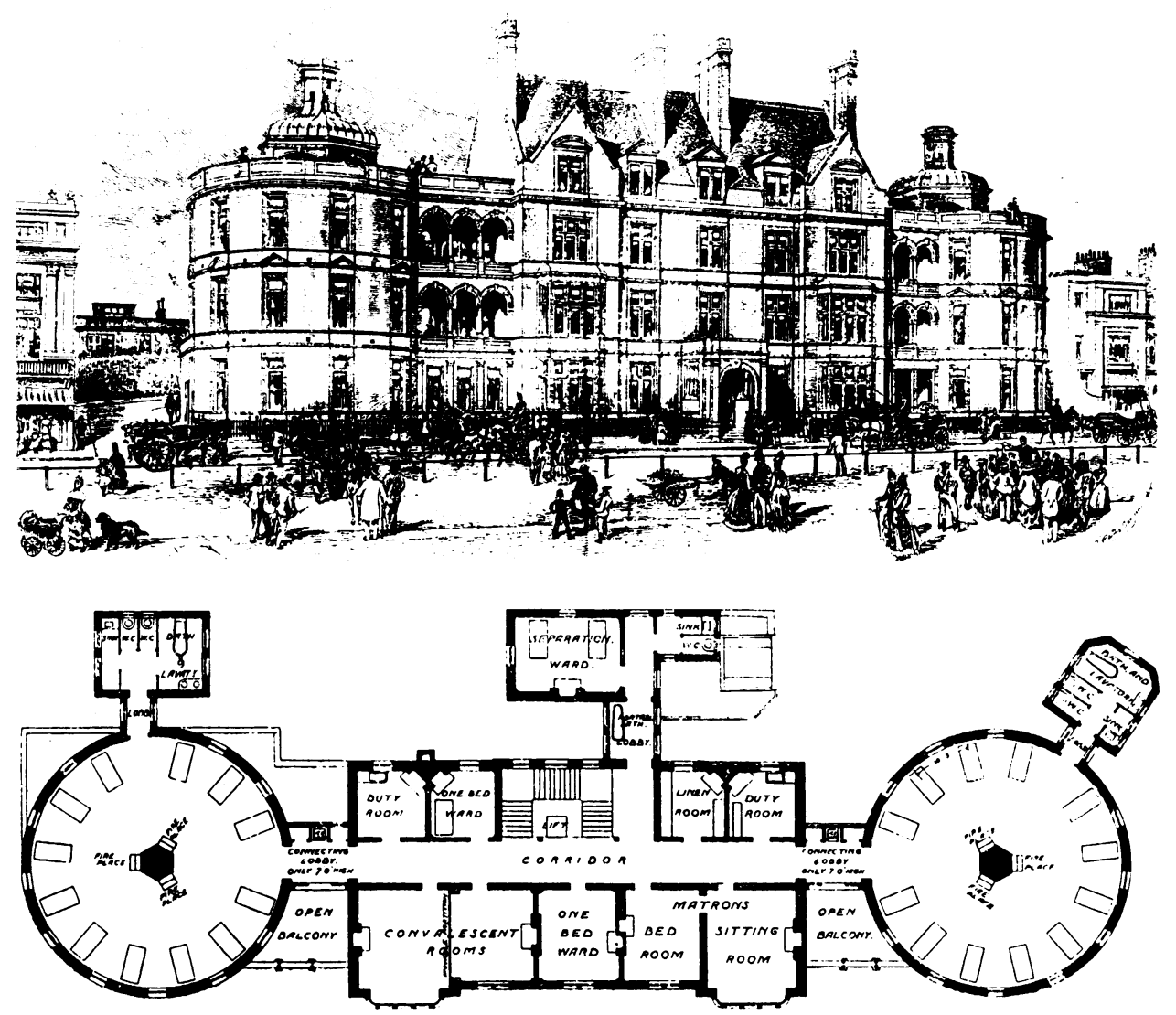

Figure 9: The Hastings, St Leonard's and East Sussex Hospital. View, plan of first and second floors. Architects Young and Hall (Builder 29 Jan 1887).

73 Ibid., pp. 907,908 and plate.

$74 \mathrm{Br}$. med. J., 1887, i: 246.

75 Ibid., 1888, i: 488. 


\section{Circular hospital wards}

format), ${ }^{76}$ Young and Hall appeared eager to make use of Professor Marshall's system. Writing in 1890, in a long paper to the Architectural Association on hospital design, Keith D. Young (whose firm was building up a notable reputation in this field) stated that

circular wards are, within certain limits, as efficient, and under certain conditions of site, superior to rectangular wards I am convinced, but the main principle involved has yet to be decided by the test of time - a test which will be applied in the new Royal Infirmary at Liverpool, now approaching completion from designs of $\mathrm{Mr}$ Waterhouse. ${ }^{77}$

This drew an immediate response from Charles Bell, the architect of the Hampstead Infirmary block, that circular wards had been in use there for six years, and were entirely satisfactory. ${ }^{78}$ But regrettably that appears to be the only comment on functioning and practical performance that was subsequently to be fed back to the architectural profession about this type of ward. Did, for instance, the smaller size circular wards for nine or ten patients prove better or worse in practice than the large units for twenty or twenty-two? Was the natural lighting and sunlight as improved (or worse) than the protagonists had hoped? Were the fears of Saxon Snell and Galton as to the problems of ventilation well founded? And did the users agree with Professor Marshall that "From its abundance of space, the curved lines of its walls, the perspective of its numerous and evenly disposed windows, and its generally diffused light, such a ward would, surely, be far more cheerful and agreeable to the eye, for both patients and attendants, than a long straight ward"? ${ }^{79}$

During the last decade of the century a number of hospital designs used circular wards. W. Henman's selected design of 1892 for Birmingham General Hospital incorporates a circular children's ward block (three floors of twelve beds each), ${ }^{80}$ although this was omitted from the revised scheme of $18933^{81}$ Alfred Waterhouse's drawings for St Mary's Hospital, Manchester (1893) show a five-storey circular block, with two twelve-bed ward floors included in the development on a very limited site; ${ }^{82}$ Salter and Adams's design for the Clarence Wing of St Mary's, Paddington (1893) has two five-bed ophthalmic wards in circular appendages; 83 the Bradford Children's Hospital had a two-storey circular ward and operating theatre added in $1900 .{ }^{84}$

76 Builder, 29 Jan. 1887, 52: 180.

${ }^{77}$ Builder, 17 May 1890, 58: 359; drawings in the RIBA Drawings Collection [Wat A (31)] show Waterhouses's proposals for two circular ward pavilions, each with 2 wards of 18 beds, to have been well advanced by early 1886 . Liverpool Royal Infirmary opened in 1890 , but, unlike the Greenwich, Burnley and Hastings inaugurations, Marshall (then 72) was unable to attend (Shonfield, op. cit., note 1 above, p. 140). The site plan for Liverpool clearly shows that the main entrance block sits between the two corners of the site which were not then in the Infirmary's possession; it was behind these unavailable corners and in front of the hospital's main cross circulation route that it was just possible to fit in the circular ward pavilions.

${ }_{78}$ Builder, 24 May 1890, 58: 380.

${ }^{79}$ Snell, op. cit., note 19 above, p. 14.

80 Builder, 26 March 1892, 62: 246-47.

81 Builder, 18 Nov. 1893, 65: 376 and plates.

82 RIBA Drawings Collection. The ground floor and basement house a lecture theatre, the first floor nurses' and pupils' accommodation. The two maternity wards on the second and third floors are $44 \mathrm{ft}$. in diameter, with 12 beds each.

${ }^{83}$ Builder, 22 July 1893, 65: 69 and plate, including a small-scale block plan.

${ }^{84}$ Noted in the Department of Environment text for statutory listing (Grade 2). 
These later essays suggest that the smaller size, or specialist use, ten-to twelve-bed ward of about 35 feet in diameter, as Keith Young had used for the 'Miller' Memorial Hospital, or Sir Andrew Clarke had adopted at Liverpool, may have continued to be seen as a useful option, ${ }^{85}$ especially where limited site space, or rights of light needed to be responded to. The larger (i.e. greater diameter) circular ward tower containing two or three ward floors of twenty-two beds each, as originally postulated by Marshall, ${ }^{86}$ and applied to a whole "notional" workhouse infirmary by H. Saxon Snell, was very much a product of the early to mid-1880s, and became to be seen as of more questionable cost effectiveness following the criticisms of 1885 , and the earlier doubts expressed by the Builder's editor George Godwin. ${ }^{87}$ That some examples of this type do still exist (e.g. at New End Hospital, Hampstead and St Giles, Camberwell) is therefore of considerable interest for both the medical and architectural historian. ${ }^{88}$

Marshall's initial ideas had been launched into that most fertile (but now largely forgotten) of environments, an annual meeting of the Social Science Association. Addressing the Health section of the Congress, he represented, as Professor of Surgery at University College Hospital, one of the "experts", the "service middle class" which, Goldman has shown, was the very essence of the Association's success. $^{89}$ As an innovative idea, therefore, it would have had the very best opportunity to flourish and to be taken seriously. But in practice, although reported in the British Medical Journal and subsequently followed up with news items about projects being built, there was not to be any published debate between doctors and designers, or between medical and sanitary reformers. What debate there was, and where the interest essentially lay, was not among the doctors but among the architectural profession and such health building specialists as Galton, Burdett and de Chaumont.

One perception of the circular ward idea was rather brusquely and inelegantly expressed by the Lancet when it referred to the Hampstead design as originating from a "suggestion thrown out" by Professor Marshall. 90 The context of this "suggestion" was the discussion of possibilities for improving the performance of the ward space which formed the essential element of the accepted pavilion hospital plan. But a more obvious advantage, and indeed one which prompted the whole proposal, was the

\footnotetext{
${ }^{85}$ Mouat and Snell, op. cit., note 22 above, had also mentioned a scheme by Dr Burdon Sanderson for circular wards purely for smallpox patients. These were to have a central chamber with an inspirator to remove foul air, and "beds would be placed with their heads against the inner chamber" with partitions between each patient. This was commented on in the Builder ( 7 July 1883, p. 3) but had not been tested.

${ }^{86}$ In his paper, Marshall recommended two or at most three ward floors superimposed, i.e. for in-town or limited area sites. The acceptable norm for pavilion hospitals at this period was often three ward floors above a ground or basement level, e.g. at St Thomas's, St George's Infirmary, and St Marylebone Infirmary; the earlier pavilion hospitals, e.g. the Herbert Hospital, Woolwich, and the General Infirmary, Leeds, had two ward floors. Of the "circular ward towers", only St Giles, Camberwell, had four ward floors, although attic floors, as at Hampstead, might be used for nurses' accommodation.

${ }^{87}$ The smaller ( 35 to 40 feet in diameter) wards would not have been so subject to accusations of wasted central space: omitting the central core, their opposing walls were little further apart than Snell's rectangular example.

${ }^{88}$ Both buildings are Department of Environment listed Grade 2. They were, at the time of writing, empty and for disposal by the National Health Service.

${ }^{89}$ L. Goldman 'The Social Science Association, 1857-1886' in Eng. hist. Rev., Jan 1986, 101: 95-134.

90 Lancet, 1884, i: 625.
} 


\section{Circular hospital wards}

potential for using a circular pavilion ward block to solve the problems of a limiting or awkward site. In such projects as Greenwich, Hampstead, the Great Northern, and the Liverpool Royal Infirmary this was an important design factor.

By the 1890s Burdett's massive Hospitals and asylums of the world clearly placed the circular ward as a subclassification in 'Pavilion Hospitals' (the sub-groups were: Single Pavilion; Double Pavilion; Multiple Pavilion, Circular Wards; Combination of Circular and Rectangular Wards; Isolated Pavilions). ${ }^{91}$ Galton in his Healthy hospitals (1893) represented a mellowed attitude to the circular ward idea, with five pages of text and illustration devoted to the format; he even noted "the form of the ward is very cheerful, because the windows catch the sunshine at a larger number of angles than ... . the rectangular form", as well as the convenience for artificial ventilation and the absence of angles. ${ }^{92}$ As he also remarked, the form had found many advocates, and the Lancet recorded, in 1887, a deputation from Denmark coming specifically to inspect the circular ward system at Greenwich, Burnley and Hastings prior to the design of a new hospital in Copenhagen. ${ }^{93}$

After 1890 circular wards nolonger reflected novel and innovative moves. The number of practical schemes related to the decade 1880-1890 can be seen as marginal in terms of the overall hospital-construction programme in England: of the schemes with circular wards, eight were built (see table). ${ }^{94}$ But as a variation in ward planning, and in the manipulation of the form of the ward space in the pavilion hospital, the idea launched at Cheltenham had achieved a recognizable place in the hospital design vocabulary of the 1890s. Despite the coincidence of the Antwerp design by Baekelmans, and an earlier proposal by Sir Andrew Clarke, the circular ward concept was clearly seen, in England, as Professor John Marshall's. He articulated it in detail in his 1878 paper, and amassed supporting architectural comment from the Architect to the Local Government Board. As a leading member of the medical profession, he addressed the architectural profession, and he actively sought discussion of his ideas to test them. After the initial, and beguiling, attractions of geometry and architectural effect had been worked through, Marshall's ideas were subject to considerable criticism on practical and cost grounds. While this may have prevented a much wider use of circular wards (despite Marshall's continuing and active promotion) a quite new and experimental building sub-type had nevertheless evolved through his efforts. His confidence in the idea, and his promotion of it, were rewarded by a widespread recognition that, as the Dictionary of National Biography flatly states, "He invented the system of circular wards for hospitals".

91 Burdett, op. cit., note 40 above, vol. 4.

92 D. Galton, Healthy hospitals, Oxford, Clarendon Press, 1893.

93 Lancet, 1887, ii: 827.

94 By comparison, over one hundred architectural competitions alone were recorded in the Builder for hospital and infirmary buildings in England during the three decades 1870-1900. See Roger H. Harper, Victorian architectural competitions, London, Mansell 1983, 336-39. 
TABLE: COMPARATIVE CIRCULAR WARD PROPOSALS 1878-1890

\begin{tabular}{|c|c|c|c|c|c|c|}
\hline Source* & Scheme & $\begin{array}{l}\text { Ward } \\
\text { diameter }\end{array}$ & $\begin{array}{l}\text { Beds/ } \\
\text { ward }\end{array}$ & $\begin{array}{l}\text { Wards/ } \\
\text { block }\end{array}$ & $\begin{array}{l}\text { Wall } \\
\text { bed }\end{array}$ & $\begin{array}{l}\text { Floor/ } \\
\text { bed }\end{array}$ \\
\hline$B 2$ NOV 1878 & $\begin{array}{l}\text { SYSTEM PROPOSAL } \\
\text { Prof. Marshall }\end{array}$ & $\begin{array}{l}61 \\
61\end{array}$ & $\begin{array}{l}22 \\
18\end{array}$ & $\begin{array}{l}3 \max \\
3 \max \end{array}$ & $\begin{array}{l}8 \\
9^{\prime} 6^{\prime \prime}\end{array}$ & $\begin{array}{l}133 \\
162\end{array}$ \\
\hline$C \& P E 1881$ & $\begin{array}{l}\text { INFIRMARY PROJECT } \\
\text { H. Saxon Snell }\end{array}$ & 70 & 32 & $3(2,4)$ & & 120 \\
\hline $\begin{array}{l}B 30 \text { JUN } 1883 \\
H C \& M 1883\end{array}$ & $\begin{array}{l}\text { ANTWERP CIVIL } \\
\text { Baeckelmans }\end{array}$ & $61^{\prime} 6^{\prime \prime}$ & 20 & 2 & & 149 \\
\hline $\begin{array}{l}B \quad 2 \text { FEB } 1884 \\
B M J \quad 3 \text { MAY } 1884\end{array}$ & $\begin{array}{l}\text { HAMPSTEAD } \\
\text { Charles Bell }\end{array}$ & 50 & 24 & 3 & $6^{\prime} 3^{\prime \prime}$ & \\
\hline B 23 AUG 1884 & $\begin{array}{l}\text { MILLER, GREENWICH } \\
\text { Young \& Hall }\end{array}$ & 35 & 10 & 2 & $\begin{array}{l}10 \\
\text { dwg }\end{array}$ & $\begin{array}{l}96 \\
\text { dwg }\end{array}$ \\
\hline$B 15$ NOV 1884 & $\begin{array}{l}\text { SEAFORTH, LIVERPOOL } \\
\text { Sir A. Clarke RE }\end{array}$ & 31 & 9 & 1 & & \\
\hline [HoW 1893] 1884 & $\begin{array}{l}\text { CANCER HOSPITAL, NEW YORK } \\
\text { Charles C. Haight }\end{array}$ & 37 & 11 & 2 & $10^{\prime} 10^{\prime \prime}$ & 103 \\
\hline B 3 JAN 1885 & $\begin{array}{l}\text { PORT SAID, EGYPT } \\
\text { Lady Strangford }\end{array}$ & $\begin{array}{l}35 \\
27\end{array}$ & $\begin{array}{r}12 \\
9\end{array}$ & & & \\
\hline$B 9$ MAY 1885 & $\begin{array}{l}\text { MILITARY, MALTA } \\
\text { Sir A. Clarke RE }\end{array}$ & 66 & 26 & 1 & 8 & 130 \\
\hline$B 26$ SEP 1885 & $\begin{array}{l}\text { CIRCULAR EXAMPLE } \\
\text { H. Saxon Snell }\end{array}$ & 66 & 22 & 3 & $8^{\prime} 8^{\prime \prime}$ & 153 \\
\hline $\begin{array}{l}R 12 \text { FEB } 1886 \\
\text { Dwgs WATA31 }\end{array}$ & $\begin{array}{l}\text { LIVERPOOL R.I. } \\
\text { Alfred Waterhouse }\end{array}$ & $\begin{array}{l}56 \\
\text { dwg }\end{array}$ & 18 & 2 & $\begin{array}{l}9^{\prime} 6^{\prime \prime} \\
\text { dwg }\end{array}$ & $\begin{array}{l}133 \\
\text { dwg }\end{array}$ \\
\hline B 30 OCT 1886 & $\begin{array}{l}\text { VICTORIA, BURNLEY } \\
\text { Waddington \& Sons }\end{array}$ & 60 & 20 & 1 & & \\
\hline B 25 DEC 1886 & $\begin{array}{l}\text { GT. NORTHERN CENTRAL } \\
\text { HOLLOWAY RD., LONDON } \\
\text { Young \& Hall }\end{array}$ & $57^{\prime} 6^{\prime \prime}$ & 20 & 3 & $8^{\prime} 6^{\prime \prime}$ & 123 \\
\hline B 29 JAN 1887 & $\begin{array}{l}\text { HASTINGS, E. SUSSEX } \\
\text { Young \& Hall }\end{array}$ & 42 & 12 & 2,3 & 10 & \\
\hline [DOE] 1888 & $\begin{array}{l}\text { ST GILES, CAMBER WELL } \\
\text { Robert P. Whellock }\end{array}$ & $57 ?$ & $20 / 21$ & 4 & & \\
\hline$B$ 18 JAN 1890 & $\begin{array}{l}\text { WEST HAM COMPETITION } \\
\text { A Crow \& P H Tree }\end{array}$ & 39 & 12 & 2 & & 100 \\
\hline
\end{tabular}

All dimensions are in feet and inches, or square feet.

*Abbreviations: $B=$ Builder

$B M J=$ British Medical Journal

$C \& P E=$ Charitable and Parochial Establishments

$H C \& M=$ Hospital Construction and Management

HoW = Hospitals and Asylums of the World

$R=$ Royal Institute of British Architects, Drawings Collection 